\title{
Effects of Sponge Encrustation on the Swimming Behaviour, Energetics and Morphometry of the Scallop Chlamys Hastata
}

Deborah Anne Donovan

Western Washington University, deborah.donovan@wwu.edu

Brian L. Bingham

Western Washington University, brian.bingham@wwu.edu

Heather M. (Heather Maria) Farren

Western Washington University

Rodolfo Gallardo

University of Maryland Eastern Shore

Veronica L. Vigilant

Southampton College

Follow this and additional works at: https://cedar.wwu.edu/esci_facpubs

Part of the Environmental Sciences Commons

\section{Recommended Citation}

Donovan, Deborah Anne; Bingham, Brian L.; Farren, Heather M. (Heather Maria); Gallardo, Rodolfo; and Vigilant, Veronica L., "Effects of Sponge Encrustation on the Swimming Behaviour, Energetics and Morphometry of the Scallop Chlamys Hastata" (2002). Environmental Sciences Faculty and Staff Publications. 2.

https://cedar.wwu.edu/esci_facpubs/2 


\title{
Effects of sponge encrustation on the swimming behaviour, energetics and morphometry of the scallop Chlamys hastata
}

\author{
Deborah A. Donovan*§, Brian L. Bingham ${ }^{\dagger}$, Heather M. Farren*, \\ Rodolfo Gallardo ${ }^{\ddagger}$ and Veronica L. Vigilant ${ }^{f}$ \\ *Department of Biology, MS 9160, Western Washington University, Bellingham, WA 98225, USA. \\ ${ }^{\dagger}$ Department of Environmental Sciences, MS 9081, Western Washington University, Bellingham, WA 98225, USA. \\ ${ }^{\ddagger}$ Department of Natural Resources, University of Maryland, Eastern Shore, Princess Anne, MD 21853, USA. \\ ${ }^{\int}$ Natural Science Division, Long Island University, Southampton College, Southampton, NY 11968, USA. \\ ${ }^{\S}$ Corresponding author, e-mail: donovan@biol.wwu.edu
}

\begin{abstract}
The effect of sponge encrustation on swimming ability of Chlamys hastata was determined by investigating swimming behaviour, scallop morphometry, and energy expended during swimming with and without commensal epibionts. Scallops swam significantly longer after sponge encrustation was removed from their shells, but no significant differences were detected in swimming elevation or distance. Scallops with sponge encrustation showed no adductor muscle hypertrophy or changes in shell morphometry compared to scallops without encrustation. However, C. hastata did exhibit scaling relationships associated with maximizing swimming efficiency. Specifically, shell width and adductor muscle mass were positively allometric with shell height, while shell mass was negatively allometric with shell height. Scallops increased their energy expenditure (both aerobic and anaerobic) during valve-clapping, but no significant difference was detected between unencrusted $(43.0 \mu \mathrm{mol}$ adenosine triphosphate [ATP] consumed during a two min escape swim) and sponge-encrusted $(40.0 \mu \mathrm{mol}$ ATP) scallops. Scallops in both treatments derived $86 \%$ of the energy used for swimming from anaerobic sources. The lack of substantial differences between scallops with and without commensal sponges is partially explained by the observation that even heavy sponge encrustation increases the immersed weight of the scallop by only $5 \%$. The presence of a sponge encrustation does not appear to inhibit swimming by this scallop species.
\end{abstract}

\section{INTRODUCTION}

Scallops are often found associated with encrusting epibionts such as sponges, barnacles, polychaete worms, bryozoans, tunicates, and algae. Of these, the scallop/ sponge relationship has received the most attention, perhaps because scallops and sponges form symbiotic relationships worldwide. However, the nature of the relationship is not always clear and the interactions between different species of sponge and scallop seem to vary. In Australia, sponge encrustation inhibits predation of the scallop Chlamys asperrima by the predatory seastar Coscinasterias calamaria by camouflaging the scallop and also by interfering with tubefoot adhesion (Pitcher \& Butler, 1987). Field studies support these conclusions since sponge cover decreases mortality of Chlamys asperrima (Chernoff, 1987). In England, the scallop Chlamys varia appears to benefit from encrustation of the sponge Halichondria panicea. In this case, the sponge interferes with adhesion of seastar tube feet and makes byssal openings in the scallop inaccessible to seastar digestive membranes, thus decreasing susceptibility of the scallops to seastar predation. The sponge also appears to benefit from this association due to an increased supply of nutrients generated from the inhalant current of the scallop (Forester, 1979).
In the Puget Sound, Washington, USA, the scallop Chlamys hastata Sowerby is often found in association with the sponges Mycale adhaerens Lambe and Myxilla incrustans Esper. The relationship was characterized as a mutualism by Bloom (1975). He determined that the scallop benefits by being less susceptible to seastar predation (in much the same way as described above for C. asperrima and C. varia). Chlamys hastata displays a dramatic escape responses to the seastar Pycnopodia helianthoides Brandt indicating that predation by this seastar must be significant in the present or in the recent past for such a response to evolve. However, the extent to which C.hastata is consumed by seastars in the field is not known and may in fact be quite low. In an exhaustive study of seastars, Mauzey et al. (1968) found very few scallops in the stomachs of seastars, indicating that predation pressure by seastars may be negligible and sponge encrustation may not benefit the scallop in the proposed way.

Bloom (1975) also suggested that the sponge benefits from the relationship by being less susceptible to nudibranch predation. In this case, the scallop swims away when jostled by dorid nudibranchs that consume sponge but are not predators of scallops. Thus, the sponge effectively escapes being eaten by being attached to a motile substratum. The sponge may also incur an additional 
benefit since, as the scallop swims or spontaneously claps its shell valves, the sponge is cleared of sediment which can clog its respiratory and feeding currents (Burns \& Bingham, unpublished data). It should be noted that, while there is some laboratory evidence that this scallop/ sponge association may be a mutualism, there is no good field evidence supporting this hypothesis.

Scallops presumably swim for a variety of reasons. Besides escaping predation (Stephens \& Boyle, 1978), scallops swim to position themselves in a better habitat (Moore \& Marshall, 1967; Peterson et al., 1982) and to migrate (Morton, 1980). Thus, even if the encrusting sponge helps the scallop escape detection and inhibits handling by seastars, it may carry costs if it decreases ability of the scallops to swim for other reasons. Furthermore, the benefits of encrustation could be outweighed by costs if the sponge increases drag or weight of the scallop enough to decrease its swimming escape from an attacking predator.

Scallops swim by clapping their shell valves together in such a way that jets of water are directed past both sides of the hinge, propelling the scallop forward in a hinge-hindmost position (Moore \& Trueman, 1971). All swimming animals must produce lift and overcome drag to move through the water. Generation of lift is aided by the buoyancy provided by water and drag can be decreased by streamlining (Denny, 1988). Relative to a clean scallop, a sponge-encrusted individual could have higher drag due to the size, shape and texture of the sponge. In addition, lift may be more difficult to generate due to the increase in mass. In this case, the scallop may not swim as effectively as it otherwise might. Evidence for these impacts could be found in the distance a sponge-encrusted scallop is able to swim or in the amount of energy it expends while swimming. Pitcher \& Butler (1987) found that C. asperrima encrusted with sponge were slower to initiate a swim from a seastar predator than are clean scallops. In addition, the magnitude (swim height + distance) of sequential responses decreased more quickly in the encrusted scallops and these scallops exhibited smaller numbers of responses with repeated stimulation. The authors were unsure about the reason for these behavioural differences but suggested that: (i) sponge encrustation could decrease the selective advantage of a strong swimming response due to the predation protection the sponge provides; or (ii) sponge encrustation physically hampers the swimming response, making the scallop less likely to swim.

The purpose of this study was to investigate different aspects of scallop swimming as a function of sponge encrustation. We looked at the effects of encrustation on swimming behaviour, energy expended by the scallop while swimming, and scallop morphometry.

\section{MATERIALS AND METHODS}

\section{Experimental animals}

Unencrusted and sponge-encrusted scallops (Chlamys hastata) were collected by SCUBA near the Shannon Point Marine Center, Anacortes, Washington. They were held in tanks with continuously flowing seawater at ambient temperature (approximately $10^{\circ} \mathrm{C}$ ) and salinity (approximately $30 \mathrm{psu}$ ). The tanks were under a window so the scallops were exposed to an ambient light regime but were never in direct sunlight.

\section{Swimming behaviour}

Scallops were videotaped during escape swimming to determine the time, distance, and elevation of swimming bouts with and without sponge encrustation. Spongeencrusted scallops $(\mathrm{N}=28)$ were placed individually in a $2.5 \mathrm{~m}$ diameter outdoor tank filled with seawater to a depth of $85 \mathrm{~cm}$. The bottom of the tank was marked with black tape to form a grid of sections measuring $30 \mathrm{~cm}$ on each side. A video camera was suspended from a scaffold over the tank so the entire bottom of the tank was in view. Individual scallops were placed in the middle of the tank. After an acclimation period (at least $10 \mathrm{~min}$ ) a seastar (Pycnopodia helianthoides) was placed next to the scallop. The swimming response that ensued was videotaped. The elevation in the water column that the scallop attained was determined by an observer watching through a port in the side of the tank. Each scallop was induced to swim three times with ten min of rest between each bout. After the scallop had swum three times with sponge encrustation, all sponge was gently removed from the scallop and placed in a weigh boat. The scallop was then weighed and returned to the holding tank. The sponge was rinsed with fresh water and dried to constant mass. After $24 \mathrm{~h}$ recovery time - a period that has been used to allow scallops to recover after swimming in other studies (e.g. Thomas \& Gruffydd, 1971), - the clean scallop was again placed in the large tank with a $P$. helianthoides and induced to swim three more times, again with 10 -min rest periods between swimming bouts.

Each videotaped swimming bout was played on a video screen and the path travelled by the scallop was traced on an acetate sheet. The trace was then scanned and the twodimensional length of the path was measured with Optimus image analysis software. The time of swimming was determined with a stopwatch.

Mean swimming time, elevation, distance and speed were determined for each individual with sponge encrustation and after the sponge had been removed. Paired $t$-tests were used to determine any differences between the treatments.

\section{Scallop morphometry}

Unencrusted $(\mathrm{N}=17)$ and sponge-encrusted $(\mathrm{N}=20)$ scallops were collected and transferred to Western Washington University, Bellingham, WA where they were held in aerated seawater at $7^{\circ} \mathrm{C}$. All morphological measurements were made within five days of the transfer.

Both shell valves of each scallop were photographed with a digital camera and the epibiont species was characterized before sacrifice. To access the soft tissues, each scallop was prised open and the adductor muscle was cut with a scalpel. The adductor muscles (both catch and phasic portions) were separated from the rest of the soft tissues and each was placed in separate aluminium weigh boats. Haemolymph was included with the body tissues. Next, all epibionts were removed from both valves of the 
shell and epibiont and shell were placed in separate aluminium weigh boats. Thus, each scallop was separated into four components (adductor muscle, soft tissue, shell, and epibiont). The wet mass of each was then recorded. These components were dried to constant mass in a $60^{\circ} \mathrm{C}$ oven for $24 \mathrm{~h}$ and dry masses were recorded. Scallop height (the distance from the dorsal hinge to the farthest point on the ventral margin) and width (the widest distance from the anterior side to the posterior side of the shell) were measured using Vernier calipers.

Shell width, dry shell mass and dry adductor mass were each regressed against shell height for both treatments. Model II regression was not used because (i) there is very little error involved in linear measurements of hard structures such as gastropod shells (e.g. Carefoot \& Donovan, 1995), and (ii) statistical analysis is more convenient with Model I regression. Since the correlation coefficients for the Model I regressions were all large (see Results), the difference between Model I and Model II regression is small (Laws \& Archie, 1981). When the Model I regression equations had been determined, analysis of covariance (ANCOVA) was used to determine if any differences existed between the slopes or intercepts of the various regressions. When no differences were found (see Results), the measurements were combined to determine the scaling relationships between scallop height and the other morphometric measurements (shell width, dry shell mass, and dry adductor muscle mass). In this case, regression analyses were performed on the combined data and the resulting slopes were compared to the expected slopes for isometry using $t$-tests.

\section{Energy consumption}

Sponge-encrusted scallops were randomly assigned to a resting treatment $(\mathrm{N}=14$; mean height $54.8 \pm 1.1 \mathrm{~mm})$ or an active treatment $(\mathrm{N}=13 ; 55.8 \pm 0.2 \mathrm{~mm})$. Unencrusted scallops were likewise assigned to a resting treatment $(\mathrm{N}=10 ; 52.9 \pm 1.0 \mathrm{~mm})$ or an active treatment $(\mathrm{N}=10$; $52.8 \pm 0.8 \mathrm{~mm})$. Scallops were placed individually into a respirometer $(400 \mathrm{ml}$ or $600 \mathrm{ml}$, depending on the size of the scallop) and oxygen consumption was monitored continuously with a polarographic oxygen electrode (Cameron Instrument Company; Pt. Aransas, Texas) connected to a computerized data acquisition system (DataQ Instruments; Akron, Ohio). Animals in the active treatment were induced to 'swim' by touching their mantle with a tube foot from the seastar $P$. helianthoides. The tube foot was introduced through a small port on the top of the respirometer which was quickly sealed after swimming began. Although movement was restricted by respirometer size, all of the scallops were able to lift themselves off the bottom after rapid valve-clapping ensued. Scallops were stimulated until exhaustion (determined by their refusal to continue valve-clapping), which usually occurred within two to three minutes. Active periods were identified on the computer file with remarks inserted during the trial. Resting animals were allowed to remain in a quiescent state throughout the run.

Immediately following the active bout in the respirometer, or after a 30-min period of quiescence for the resting group, the scallops were rapidly removed from their shells and the adductor muscles were freeze clamped in liquid nitrogen. Removal of a scallop from the respirometer and the muscle from the scallop took less than one minute. Muscle tissue was then stored in liquid nitrogen until analysis. Some scallops that had swum in the respirometer long enough to record an oxygen consumption but were not deemed exhausted were not used for anaerobic metabolite analyses.

After the sponge-encrusted scallops were tested and dissected, the encrusted shells were returned to the respirometer to determine the oxygen consumption of the sponge. This value was subtracted from the scallop/sponge oxygen consumption to determine the oxygen consumption of the scallop alone.

To measure anaerobic metabolites, approximately $1 \mathrm{~g}$ of the frozen adductor muscle was homogenized in a test tube with $9 \mathrm{ml}$ of $10 \%$ trichloroacetic acid using an Ultraturrax tissue disrupter. The homogenates were centrifuged at $5000 \mathrm{rpm}$ for $15 \mathrm{~min}$ at $4^{\circ} \mathrm{C}$ and the supernatant pipetted off. Supernatants were neutralized with $5 \mathrm{M} \mathrm{NaOH}$. Octopine levels were determined spectrophotometrically (HP 8452A spectrophotometer) by following the reduction of $\mathrm{NAD}^{+}$at $340 \mathrm{~nm}$ (Grieshaber, 1976). Arginine and arginine phosphate levels were measured spectrophotometrically following the method of Gade (1985).

Two-way analysis of variance (ANOVA) was used to determine if differences occurred between the treatments, with activity (resting and swimming) and encrustation (unencrusted and sponge encrusted) used as the main effects.

\section{Scallop/sponge masses}

To assess the impact sponge mass has on submerged scallop weight, scallops $(\mathrm{N}=5)$ with moderate to heavy sponge encrustation were weighed underwater. A Mettler 160 scale (precision $=0.001 \mathrm{~g}$ ) with a hook extending from the bottom was placed over a large bucket of seawater $\left(10^{\circ} \mathrm{C}\right)$ and a wire basket to hold the scallops was attached to the hook. The scallops were kept submerged in water while they were transferred to the bucket to ensure that no air was trapped in the mantle cavity or in the sponge. After the scallops with sponge encrustation had been weighed in water, they were weighed in air (for reference to other scallops in this study which were weighed in air) then the sponge was carefully scraped off into a weigh boat. The scallop was weighed again in air and returned to the bucket where it was allowed to open up so any air bubbles trapped in the mantle cavity could escape. The scallop was then weighed in water without sponge encrustation. The sponge was rinsed with freshwater to remove salts, dried to constant mass at $60^{\circ} \mathrm{C}$, and weighed.

A paired $t$-test was used to determine if any difference existed between immersed weight with sponge encrustation and without sponge encrustation.

\section{RESULTS}

\section{Swimming behaviour}

There was no evidence that scallops tired during the three spaced swimming bouts as there was no drop in swimming ability or decreased reaction to the predator over the course of the trials. 
Table 1. Swimming behaviour of scallops with sponge encrustation and after the sponge had been removed. $\mathcal{N}$ umbers represent grand means $\pm S E$ of three trials for each of 28 scallops.

\begin{tabular}{lcccc}
\hline & With sponge & Without sponge & $\begin{array}{c}\text { Paired } t \text {-test } \\
\text { (2-tailed) }\end{array}$ & Power \\
\hline Time $(\mathrm{s})$ & $8.6 \pm 0.2$ & $9.36 \pm 0.3$ & $t=2.74 ; P=0.01$ & \\
Elevation $(\mathrm{cm})$ & $71.6 \pm 3.0$ & $72.76 \pm 3.3$ & $t=0.36 ; P=0.72$ & 0.09 \\
Distance $(\mathrm{cm})$ & $150.4 \pm 5.4$ & $155.36 \pm 4.7$ & $t=0.95 ; P=0.35$ & 0.23 \\
Horizontal speed $\left(\mathrm{m} \mathrm{s}^{-1}\right)$ & $0.18 \pm 0.01$ & $0.176 \pm 0.01$ & $t=0.68 ; P=0.51$ & 0.26 \\
\hline
\end{tabular}

Table 2. Scaling of swimming related morphometric relationships in the scallop Chlamys hastata. Values from the treatment groups (unencrusted and sponge-encrusted) were combined $(\mathcal{N}=37)$ since preliminary analyses showed no statistical difference between the treatments (see text). Data were $\log _{10}$-transformed before a least-squares regression was fit to them. All equations were in the form of $\log _{10} \mathrm{Y}=\log _{10} \mathrm{a}+\mathrm{b} \log _{10}$ $\mathrm{X}$, where $b$ is the slope of the line and $a$ is the intercept.

\begin{tabular}{lcccccc}
\hline $\log _{10} Y_{\text {on }} \log _{10} X$ & $\log a$ & $b$ & $\begin{array}{c}\text { Expected } b \\
\text { for isometry }\end{array}$ & $r^{2}$ & $t$ & $P$ \\
\hline Shell length on shell height & -0.24 & 1.12 & 1 & 0.98 & 4.06 & $<0.001$ \\
Shell mass on shell height & -3.40 & 2.49 & 3 & 0.95 & 5.10 & $<0.001$ \\
Adductor mass on shell height & -6.39 & 3.59 & 3 & 0.93 & 3.49 & $<0.002$ \\
\hline
\end{tabular}

Average sponge dry mass for the 28 scallops tested was $0.63 \pm 0.08 \mathrm{~g}$ (all values are means $\pm \mathrm{SE}$ ), with a range of $0.1-2.2 \mathrm{~g}$. Scallops swam significantly longer after encrusting sponge had been removed (Table 1), spending an average of $0.7 \mathrm{~s}$ longer in the water column. There were no significant differences in swimming distance, elevation or speed the scallops swam. Despite good replication $(\mathrm{N}=28)$ and a powerful test (a paired $t$-test), calculated power was low for these analyses, indicating that effect sizes were very small.

\section{Scallop morphometry}

No differences were detected in the slopes $\left(t_{0.05(2), 33}=0.180 ; P>0.5\right)$ or the intercepts $\left(t_{0.05(2), 34}=0.179\right.$; $P>0.5)$ of the regression equations describing the relationships between scallop height and scallop width for unencrusted and sponge-encrusted scallops. Likewise, no differences were detected for the dry shell mass vs scallop height relationships (slopes: $t_{0.05}(2), 33=0.190 ; P>0.5$; intercepts $\left.t_{0.05}(2), 34=0.338 ; P>0.5\right)$ and the dry adductor mass vs scallop height relationship (slopes: $t_{0.05(2), 33}=0.832$; $P=0.43$; intercepts $\left.t_{0.05(2), 34}=1.803 ; P=0.08\right)$.

Since no differences in morphometry were evident among the treatments, the scallops were combined to determine scaling relationships. It was found that both shell width and adductor muscle mass were positively allometric with shell height, indicating that both of these variables increased to a greater extent than they would in an isometrically growing animal when compared to scallop height. Shell mass was negatively allometric with shell height (Table 2).

\section{Energy consumption}

Unencrusted scallops approximately doubled their oxygen consumption from an average of $34.6 \mu \mathrm{L} \mathrm{O}_{2} \mathrm{~g}^{-1} \mathrm{~h}^{-1}$ during the resting state to an average of $62.0 \mu \mathrm{L} \mathrm{O}_{2} \mathrm{~g}^{-1} \mathrm{~h}^{-1}$ during the active state (Figure 1). Likewise, spongeencrusted scallops increased their oxygen consumption from an average of $27.6 \mu \mathrm{L} \mathrm{O}_{2} \mathrm{~g}^{-1} \mathrm{~h}^{-1}$ during the resting state to an average of $53.6 \mu \mathrm{L} \mathrm{O}_{2} \mathrm{~g}^{-1} \mathrm{~h}^{-1}$ during the active state. Activity level (resting or active) had a significant effect on oxygen consumption $\left(F_{1,43}=18.54\right.$; $P<0.001$ ) but neither encrustation (unencrusted or sponge encrusted; $F_{1,43}=1.51 ; P=0.23$; observed power $=$ $0.23)$ nor the interaction between activity and encrustation $\left(F_{1,43}=0.013 ; P=0.91\right.$; observed power $\left.=0.05\right)$ had significant effects. Thus, oxygen consumption was greater in active scallops than in resting scallops but no difference in oxygen consumption between unencrusted and spongeencrusted scallops was detected.

Activity level (resting or active) had a significant effect on both octopine $\left(F_{1,33}=34.40 ; P<0.001\right.$; Table 3$)$ and arginine phosphate levels $\left(F_{1,33}=22.50 ; P<0.001\right)$, but neither encrustation (unencrusted or sponge encrusted; $F_{1,33}$ both $<1.10$ for octopine and arginine phosphate; $P$ both $>0.30$; observed power both $<0.18$ ) nor the interaction between activity and encrustation $\left(F_{1,33}\right.$ both $<0.10$; $P$ both $>0.75$; observed power both $<0.06)$ had significant effects. These data indicate that scallops use anaerobic energy sources during valve-clapping, but increased expenditure by sponge-encrusted scallops was not detected.

\section{Scallop/sponge masses}

Sponge mass contributed significantly (paired $t_{0.05(2), 4}$ $=5.53, P=0.005)$ but slightly to immersed scallop/sponge weight. When moderate to heavy sponge encrustation was removed, immersed scallop weight decreased by $0.42 \pm 0.08 \mathrm{~g}$ (from $7.86 \pm 0.69 \mathrm{~g}$ to $7.44 \pm 0.68 \mathrm{~g}$ ) which represented $5.3 \pm 0.9 \%$ of the original scallop/sponge association weight. 


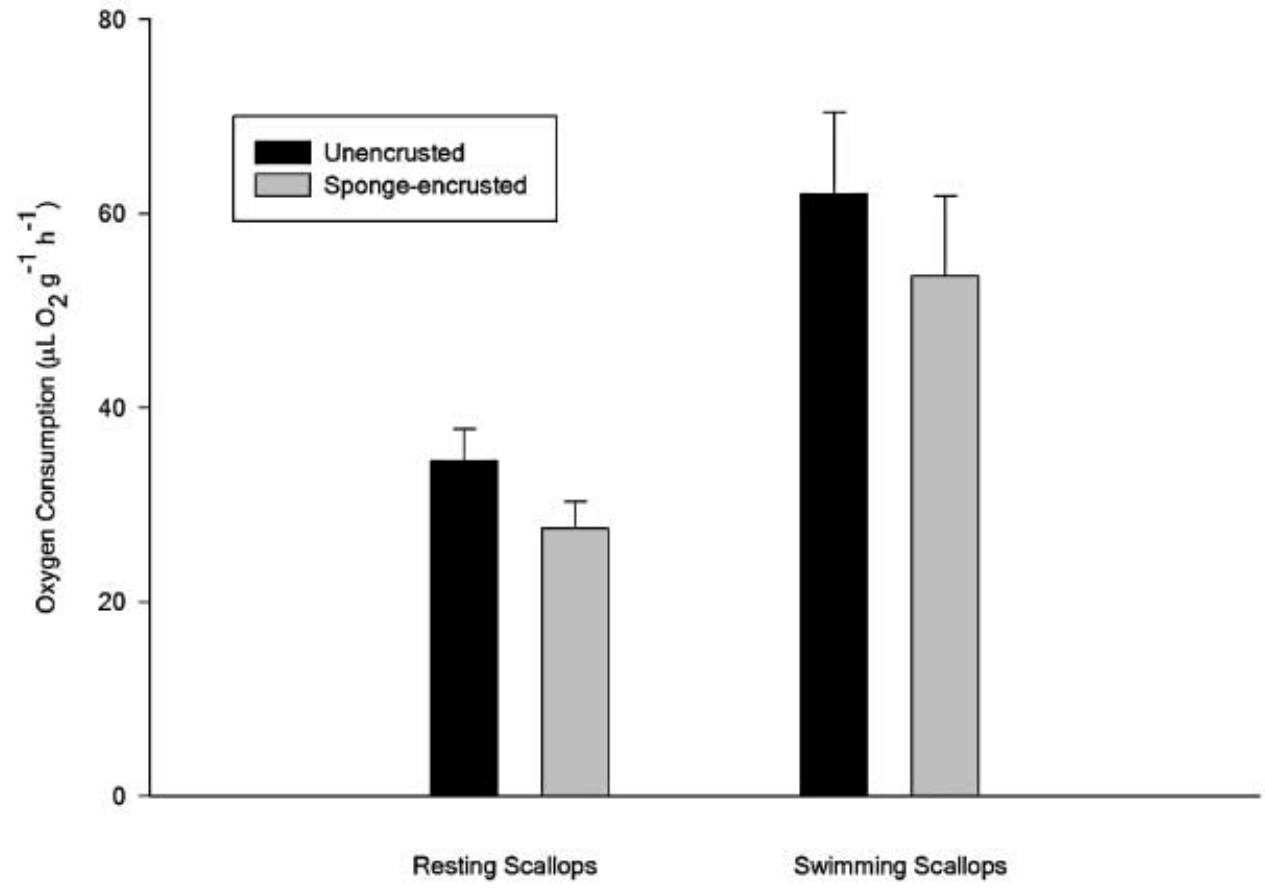

Figure 1. Mean mass specific oxygen consumption of scallops resting and swimming with and without sponge encrustation. Error bars represent SE. Activity level significantly affected oxygen consumption (see text for ANOVA results) but no effect of sponge encrustation was detected.

Table 3. Anaerobic metabolites accumulated during swimming in scallops with and without sponge encrustation. Values are mean $\pm S E$. Results of two-way ANOVA are in the text.

\begin{tabular}{lcccr}
\hline & \multicolumn{3}{c}{ Metabolite levels $\left(\mu \mathrm{molg}\right.$ muscle $\left.^{-1}\right)$} & \\
\cline { 2 - 4 } & $\begin{array}{c}\text { Unencrusted } \\
\text { resting } \\
(\mathrm{N}=7)\end{array}$ & $\begin{array}{c}\text { Unencrusted } \\
\text { swimming } \\
(\mathrm{N}=10)\end{array}$ & $\begin{array}{c}\text { Sponge- } \\
\text { encrusted resting } \\
(\mathrm{N}=11)\end{array}$ & $\begin{array}{c}\text { Sponge-encrusted } \\
\text { swimming } \\
(\mathrm{N}=10)\end{array}$ \\
\hline $\begin{array}{l}\text { Octopine } \\
\text { Arginine phosphate }\end{array}$ & $0.7 \pm 0.09$ & $3.0 \pm 0.4$ & $0.8 \pm 0.2$ & $3.1 \pm 0.5$ \\
& $8.5 \pm 3.0$ & $1.4 \pm 0.8$ & $6.6 \pm 1.3$ & $0.3 \pm 0.2$ \\
\hline
\end{tabular}

\section{DISGUSSION}

The association between the scallop Chlamys hastata and the sponges Mycale adhaerens and Myxilla incrustans has been classified as a mutualism due to laboratory evidence that both scallop and sponge are less susceptible to predation when they coexist (Bloom, 1975). A mutualism occurs if both species benefit from the association and this would be the case in this scallop/sponge association if escape from predation was the only factor involved and if it really contributed to protection. Until now the costs of carrying an epibiont load for the scallops have not been evaluated. If it were found that sponge encrustation significantly affected swimming by the scallop, either by decreasing the time or distance of swimming or by increasing the energy expended during swimming, the association could be viewed as parasitism. Or, if the purported benefits of escaping seastar predation were balanced by increased costs of swimming, the association could be classified as commensalism (assuming, of course, that the sponge benefits from the relationship).
In this study, removal of sponge encrustation allowed scallops to swim longer $(0.7 \mathrm{~s}$; Table 1$)$. Although this difference is small, it could have important implications. It has been shown that small scallops rely mainly on currents for horizontal displacement (Manual \& Dadswell, 1991; Minchin, 1992) and that horizontal displacement for larger Placopecten magellanicus is also a function of current speed (Carsen et al., 1996). It has also been found that the scallop Chlamys islandica is more likely to swim as current speed increases (Gruffydd, 1976). Chlamys hastata generally occur in habitats that receive strong currents (up to $4.3 \mathrm{~m} \mathrm{~s}^{-1}$ during a spring tide and $1.0 \mathrm{~ms}^{-1}$ during a more average tidal exchange). A scallop that swims up off the bottom, therefore, benefits from transport by currents as well as from its own swimming action. This could be a significant benefit if a scallop is being pursued by a large or very mobile predator and this effect could be compounded if the scallops are in habitats with high relief. Thus, sponge encrustation may have a cost even given the relatively small decrease in time of swimming with encrustation. 
Swimming ability could be maximized with changes in scallop shell or muscle morphology. Swimming ability and shell morphology vary among scallop species and it is well documented that some scallops have shapes that increase lift and decrease drag. For example, P. magellanicus is a long distance, level swimmer (Caddy, 1968) that is streamlined and upper-convex, allowing lift to be generated through the Bernoulli effect (Stanley, 1970). As well, Amusium sp. from the western Pacific are streamlined and have unique shapes that minimize drag (Hayami, 1991). These species are excellent swimmers, covering relatively long distances with level swimming and gliding during escape swims. Other species of scallops have forms that are less conducive to swimming (they may be lower-convex or eqiconvex); these species generally swim upward for relatively short periods of time to escape predation then fall back to the substratum (Stanley, 1970). That C. hastata falls into the latter group is evident by its swimming behaviour. Mean horizontal velocity was only $0.17 \mathrm{~m} \mathrm{~s}^{-1}$ (Table 1). This velocity is not unusual for slow-swimming species (Moore \& Trueman, 1971). More efficient scallop swimmers exhibit velocities from $0.6-1.6 \mathrm{~m} \mathrm{~s}^{-1}$ (Caddy, 1968; Morton, 1980; Joll, 1989).

While it is unlikely that scallops respond to epibiont encrustation with extreme changes in shell shape such as those described above, more subtle changes could occur. Scallops have a variety of intraspecific ontogenic changes in morphology that enhance swimming, and these could more easily be manipulated to compensate for epibionts. For example, shells of long-swimming pectinids are comparatively thin (Hayami \& Okamoto, 1986) and relative thinning of the shell occurs as these scallops grow, making lift easier to generate with increasing mass (Hayami \& Hosoda, 1988). Shell width is also usually positively allometric with shell height in swimming pectinids (that is, shells become relatively broader as scallops grow), which increases the aspect ratio and makes swimming more efficient by decreasing drag (Hayami, 1991). Muscle mass is also positively allometric with shell height, increasing the relative power that can be generated by larger scallops (Gould, 1971).

However, changes in morphometry that might enhance swimming were not detected in $C$. hastata encrusted with epibiont sponge. There were no statistical differences between the slopes and the intercepts of the regression equations of adductor muscle mass on scallop height for unencrusted and sponge-encrusted scallops, indicating that muscle mass increases with size in the same manner in these two groups. Muscle mass (expressed as a percentage of soft tissue mass) has been found to increase in P. magellanicus induced to swim more frequently than a control group (Kleinman et al., 1996), indicating that increased work associated with swimming can cause muscle hypertrophy in scallops. In addition, C. hastata did not compensate for epibiont loads by changing the amount of shell they produce. These findings are contrary to changes in soft tissue and shell mass found in C. asperrima encrusted with crellid sponge (Pitcher \& Butler, 1987). These scallops had thinner shells due to less secretion of shell material than scallops with no encrustation, possibly because 'unencrusted' $C$. asperrima were attacked by boring organisms and needed to repair their shells more often. In addition, sponge-encrusted $C$. asperrima had larger shells at a given age, enabling them to accommodate more soft tissue than unencrusted scallops. It should be noted that no attempt was made to estimate the age of the scallops in this study. However, unencrusted C. hastata generally have shells devoid of boring organisms and we saw no indication that growth was any different in unencrusted vs sponge-encrusted scallops. It is interesting that the scallop species which are highly proficient swimmers are rarely encrusted with epibionts (Hayami, 1991). Specifically, Amusium shells are very shiny and are only encrusted in later life stages. Likewise, epibionts occur primarily on large P. magellanicus after their swimming ability is lost due to size (Caddy, 1968; Dadswell \& Weihs, 1990).

Although no morphometric differences were found with epibiont encrustation, C. hastata did exhibit changes in morphometry with increasing size. As they grew, their shells became relatively broader and lighter, and their adductor muscles grew relatively bigger (Table 2). All of these changes are exhibited by other scallop species (Gould, 1971) and serve to increase the efficiency of swimming. Broader shells increase the aspect ratio (the ratio of shell width to height) which tends to decrease drag, while a relative decrease in shell mass decreases the lift that must be generated to swim. Increasing muscle mass increases the power that can be generated during swimming. These morphometric changes are evident in the majority of swimming scallops, whether they are long distance, efficient swimmers (Placopecten, Amusium) or whether they are less efficient swimmers such as Chlamys.

No differences were detected in the amount of energy expended by sponge-encrusted scallops, compared to unencrusted scallops, during rapid valve-clapping which approximated an escape swim. Chlamys hastata rely mostly on anaerobic energy for swimming, with production of glycolytically derived octopine and hydrolysis of arginine phosphate in the adductor muscle, as reported for other scallops (Grieshaber \& Gade, 1977; Baldwin \& Opie, 1978; Gade et al., 1978; Grieshaber, 1978; Livingstone et al., 1981). A representative $25 \mathrm{~g} \mathrm{C.} \mathrm{hastata}$ has approximately $3.5 \mathrm{~g}$ of adductor muscle (wet muscle mass is $14.1 \pm 1.2 \%$ of total scallop mass; Donovan \& Farren, unpublished data). During a two min swim until exhaustion (the usual time spent valve-clapping in the respirometer), a clean scallop accumulates $2.3 \mu \mathrm{molg}$ muscle $^{-1}$ of octopine and hydrolyses $7.1 \mu \mathrm{molg}$ muscle $^{-1}$ of arginine phosphate (Table 3). Assuming conversions of $1.5 \mu \mathrm{mol}$ adenosine triphosphate (ATP) per $\mu \mathrm{mol}$ octopine and $1.0 \mu \mathrm{mol}$ ATP per $\mu \mathrm{mol}$ arginine phosphate, these metabolites yield $12.1 \mu \mathrm{mol}$ ATP from octopine and $24.8 \mu \mathrm{mol}$ ATP from arginine phosphate for a total of $36.9 \mu \mathrm{mol}$ ATP from anaerobic metabolism. Aerobically, the $25 \mathrm{~g}$ scallop swimming for two min will consume $27.4 \mu \mathrm{L} \mathrm{O}_{2}$ $\mathrm{g}^{-1} \mathrm{~h}^{-1}$ above resting metabolism (Figure 1). Assuming $6 \mu \mathrm{mol}$ ATP are derived from each $\mu \mathrm{mol} \mathrm{O}_{2}$ consumed, this yields a total of $6.1 \mu \mathrm{mol}$ ATP from aerobic energy sources. Thus a total of $43.0 \mu \mathrm{mol}$ ATP are consumed during a two min swimming bout, $86 \%$ of which was derived anaerobically. The same calculations, performed for sponge-encrusted scallops, yield a total energy expenditure of $40.0 \mu \mathrm{mol}$ ATP for a two min swim, $86 \%$ from anaerobic sources. These figures are slightly less than those of the scallop P. magellanicus during exhaustive swimming. In this species, $95 \%$ of its total swimming energy is 
derived from anaerobic sources (71\% from arginine phosphate, $13 \%$ from ATP, and 11\% from octopine formation) (Livingstone et al., 1981). However, since we did not measure cellular ATP stores, we have probably underestimated the total contribution from anaerobic energy sources for C. hastata.

The lack of a larger effect of sponge encrustation on scallop swimming (e.g. shorter distance or lower elevations) is partially explained by the observation that even heavy encrustation does not increase the immersed mass of the scallop by very much. This implies that the lift the scallops must generate while swimming is much the same whether they are encrusted by sponge or not. Swimming animals must generate enough lift to counteract the force of gravity on their mass to stay afloat and, in this case, the mass of the scallop increases by only $5 \%$ with moderate to heavy encrustation.

Sponge encrustation in the sponge/scallop association common to Puget Sound does not seem to adversely affect the scallop's ability to swim, save for a decrease in swimming duration. However, other organisms such as balanoid barnacles, polychaete worms, bryozoans, and tunicates are also known to settle on C. hastata. It is possible that these heavier, less streamlined organisms could have much larger impacts on swimming ability. In fact, preliminary observations of scallops swimming with barnacle encrustation indicate that both swimming distance and height are negatively affected and investigations into the effects that balanoid barnacles have on scallop drag, swimming behaviour, and energetics are currently underway.

We wish to thank the faculty and staff at Shannon Point Marine Center for research space and support. In particular, Gene McKeen, Gisele Muller-Parker, and Nathan Schwarck helped immensely during scallop collection. Parts of this work were supported by National Science Foundation grants OCE 9731144 (Research Experience for Undergraduates) and OCE 9729316 (Minorities in Marine Science Undergraduate Programme).

\section{REFERENCES}

Baldwin, J. \& Opie, A.M., 1978. On the pole of octopine dehydrogenase in the adductor muscles of bivalve molluscs. Comparative Biochemistry and Physiology, 61B, 85-92.

Bloom, S.A., 1975. The motile escape response of a sessile prey: a sponge-scallop mutualism. Fournal of Experimental Marine Biology and Ecology, 179, 311-321.

Caddy, J.F., 1968. Underwater observations on scallop (Placopecten magellanicus) behaviour and drag efficiency. Fournal of the Fisheries Research Board of Canada, 25, 2123-2141.

Carefoot, T.H. \& Donovan, D.A., 1995. Functional significance of varices in the muricid gastropod Ceratostoma foliatum. Biological Bulletin. Marine Biological Laboratory, Woods Hole, 189, 59-68.

Carsen, A.E., Hatcher, B.G. \& Scheibing, R.E., 1996. Effect of flow velocity and body size on swimming trajectories of sea scallops, Placopecten magellanicus (Gmelin): a comparison of laboratory and field measurements. Fournal of Experimental Marine Biology and Ecology, 203, 223-243.

Chernoff, H., 1987. Factors affecting mortality of the scallop Chlamys asperrima (Lamarck) and its epizoic sponges in South Australian waters. Fournal of Experimental Marine Biology and Ecology, 109, 155-171.
Dadswell, M.J. \& Weihs, D., 1990. Size-related hydrodynamic characteristics of the giant scallop Placopecten magellanicus (Bivalvia: Pectinidae). Canadian Fournal of Zoology, 68, 778-785.

Denny, M.W., 1988. Biology and the mechanics of the wave-swept environment. Princeton, New Jersey: Princeton University Press.

Forester, A.J., 1979. The association between the sponge Halichondria panicea (Pallas) and scallop Chlamys varia (L.): a commensal protective mutualism. Fournal of Experimental Marine Biology and Ecology, 36, 1-10.

Gade, G., 1985. Arginine and arginine phosphate. In Methods of enzymatic analysis, vol. VIII (ed. H.U. Bergmeyer), pp. 424-431. Weinheim: Verlag Chemie.

Gade, G., Weeda, E. \& Gabbott, P.A., 1978. Changes in the level of octopine during the escape responses of the scallop, Pecten maximus (L.). Fournal of Comparative Physiology, 124B, 121-127.

Gould, S.J., 1971. Muscular mechanics and the ontogeny of swimming in scallops. Paleontology, 14, 61-94.

Grieshaber, M., 1976. An enzymatic method for the estimation of octopine. Analytical Biochemistry, 74, 600-603.

Grieshaber, M., 1978. Breakdown and formation of high-energy phosphates and octopine in the adductor muscle of the scallop, Chlamys opercularis (L.), during escape swimming and recovery. Fournal of Comparative Physiology, 126B, 269-276.

Grieshaber, M. \& Gade, G., 1977. Energy supply and the function of octopine in the adductor muscle of the scallop, Pecten jacobaeus (Lamarck). Comparative Biochemistry and Physiology, 58B, 249-252.

Gruffydd, L.D., 1976. Swimming in Chlamys islandica in relation to current speed and an investigation of hydrodynamic lift in this and other scallops. Norwegian Fournal of Zoology, 24, $365-378$.

Hayami, I., 1991. Living and fossil scallop shells as airfoils: an experimental study. Paleobiology, 17, 1-18.

Hayami, I. \& Hosada, I., 1988. Fortipecten takahashii, a reclining pectinid from the Pliocene of north Japan. Paleontology, 31, $419-444$.

Hayami, I. \& Okamoto, T., 1986. Geometric regularity of some oblique sculptures in pectinid and other bivalves: recognition by computer simulations. Paleobiology, 12, 433-449.

Joll, L.M., 1989. Swimming behaviour of the saucer scallop Amusium balloti (Mollusca: Pectinidae). Marine Biology, 102, 299-305.

Kleinman, S., Hatcher, B.G. \& Scheibling, R.E., 1996. Growth and content of energy reserves in juvenile sea scallops, Placopecten magellanicus, as a function of swimming frequency and water temperature in the laboratory. Marine Biology, 124, 629-635.

Laws, E.A. \& Archie, J.W., 1981. Appropriate use of regression analysis in marine biology. Marine Biology, 65, 13-16.

Livingstone, D.R., Zwaan, A. de \& Thompson, R.J., 1981. Aerobic metabolism, octopine production and phosphoarginine as sources of energy in the phasic and catch adductor muscles of the giant scallop Plactopecten magellanicus during swimming and the subsequent recovery period. Comparative Biochemistry and Physiology, 70B, 35-44.

Manuel, J.L. \& Dadswell, M.J., 1991. Swimming behaviour of juvenile giant scallop, Placopecten magellanicus, in relation to size and temperature. Canadian Fournal of Zoology, 69, $2250-2254$.

Mauzey, K.P., Birkeland, C. \& Dayton, P.K., 1968. Feeding behavior of asteroids and escape responses of their prey in the Puget Sound region. Ecology, 49, 603-619.

Minchin, D., 1992. Biological observations on young scallops Pecten maximus. Fournal of the Marine Biological Association of the United Kingdom, 72, 807-819.

Moore, J.D. \& Trueman, E.R., 1971. Swimming of the scallop, Chlamys opercularis (L.). Fournal of Experimental Marine Biology and Ecology, 6, 179-185. 
Moore, J.K. \& Marshall, N., 1967. An analysis of the movements of the bat scallop, Aequipecten irradians, in a shallow estuary. Proceedings of the National Shellfish Association, 57, 77-82.

Morton, B., 1980. Swimming in Amusium pleuronectes (Bivalvia: Pectinidae). Fournal of Zoology, 190, 375-404.

Peterson, C.H., Ambrose, W.G. Jr \& Hunt, J.H., 1982. A field test of the swimming response of the bay scallop (Argopecten irradians) to changing biological factors. Bulletin of Marine Science, 32, 939-944.

Pitcher, C.R. \& Butler, A.J., 1987. Predation by asteroids, escape response, and morphometrics of scallops with epizoic sponges. Fournal of Experimental Marine Biology and Ecology, 112, 233-249.
Stanley, S.M., 1970. Relation of shell form to life habits in the Bivalvia (Mollusca). Geological Society of America Memoir, 125, $1-296$.

Stephens, P.J. \& Boyle, P.R., 1978. Escape responses of the queen Chlamys opercularis (L.) (Mollusca: Bivalvia). Marine Behaviour and Physiology, 5, 103-113.

Thomas, G.E. \& Gruffydd, L.D., 1971. The types of escape reactions elicited by the scallop Pecten maximus by selected seastar species. Marine Biology, 10, 87-93.

Submitted 29 November 2001. Accepted 8 April 2002. 